\title{
焼結低合金鋼の高性能化に向けたメソヘテロ組織制御
}

\author{
松田 光弘出 ${ }^{2}$ ，三浦 秀士虾 \\ 1 1 熊本大学大学院自然科学研究科, 干 860-8555 熊本市黒髪 2-39-1. \\ 中2 熊本大学工学部知能生産システム工学科,
}

\section{Mezzo-Heterogeneous Microstructural Control for High Performance Sintered Low Alloy Steels}

\author{
Mitsuhiro Matsuda ${ }^{\text {h } 1}$ and Hideshi Miura ${ }^{\text {th } 2}$ \\ * 1 Graduate School, Kumamoto University, 2-39-1 Kurokami, Kumamoto 860-8555. \\ ${ }^{2}$ Dept. Mech. Eng. \& Materials Sci., Kumamoto University, 2-39-1 Kurokami, Kumamoto 860-8555.
}

Received February 10, 2000

\section{SYNOPSIS}

In our previous studies on the 4600 steels produced by Metal Injection Molding (MIM) process using mixed elemental powder, the fine heterogeneous microstructure caused by the agglomeration of Ni powders was reported to be significantly effective for the improvement of mechanical properties. This study has been performed to clarify and optimize the relationship between the mechanical properties and the heterogeneous microstructure for ultrahigh strengthening the sintered low alloy steels ( 4600 grade, 0.4 mass $\% \mathrm{C}$ ) produced by MIM process varying Ni content from 0 to 8 mass $\%$.

The tensile and fatigue strength were improved significantly with increasing Ni content to 6 mass $\%$, without loss of the ductility. This seemed to be due to the solution strengthening and the mezzo-heterogeneous microstructure which were consisted of $\mathrm{Ni}$ rich martensite surrounded by a network of tempered martensite. However, the tensile and fatigue strength of the steel added 8 mass $\% \mathrm{Ni}$ were dropped by the increase of retained austenite.

\section{KEY WORDS}

metal injection molding, 4600 steels, Ni content, heterogeneous microstructure, mechanical properties

\section{1 緒 言}

鉄系焼結材料は機械構造用部品として多用されており,その 需要も順調に払大しているが,自動車を始めとする各種機械構 造物の高性能化に伴い,必然的に過酷な負荷に耐えうる高強度 な焼結材料が切望されている. 金属粉末射出成形(MIM) 法に よれば,従来の粉末治金法(プレス成形)に比べて高密度で高 性能な焼結材料を得ることができる ${ }^{1)}$. 著者らは以前に, MIM 法による熱処理した 4600 鋼 (Fe-1.8mass\%Ni-0.5mass\%Mo$0.2 \mathrm{mass} \% \mathrm{Mn}$ )において,混合粉末を用いた微細不均質(メソへ テロ)組織の方が合金粉末を用いた均質組織よりも優れた機械 的性質を示すことを報告 ${ }^{23)}$ した。前者では，添加合金元素粉 末の1つであるNiの偏析により出現した高硬度なマルテンサ イト相を網目状に焼もどしマルテンサイト相が取り囲んだ組 織を呈しており，このユニークな組織形態が強度の向上に大 きく寄与したものと考えられた．したがって，このメゾへテ 口組織におよほす $\mathrm{Ni}$ 量の影響は大きく，またNiの分散状態に よっては機械的性質も大きく変化すると予想される。
本研究では，MIM 法により作製した Fe-Ni-Mo 系焼結低合 金鋼の熱処理材において，とくに高強度自動車部品材料とし ての用途を図るため，メソへテロ組織を利用して静的のみな らず動的破壊強度の飛躍的な向上を得るためのNi添加量, な らびにメゾへテロ組織の最適化について調查, 検討した.

\section{2 実験方法}

原料粉末には，カーボニル Fe粉に Ni, Mo, Fe-Mn などの各 種元素粉を $\mathrm{Fe}-(0,2,4,6,8) \mathrm{Ni}-0.5 \mathrm{Mo}-0.2 \mathrm{Mn}$ (mass\%) の組成と なるように添加混合したものを使用した. 各種元素粉末の諸 特性を Table 1 に示す. バインダにはパラフィンワックス (69mass\%), ポリプロピレン (20mass\%), カルナウバワックス (10mass\%) およびステアリン酸(1mass\%) で構成される多成分 ワックス系バインダを使用し，粉末とバインダを体積比で60:40 となるように配合し，418Kで $1.8 \mathrm{ks}$ 加熱混鍊後，冷却粉砕し， 横型スクリュー式射出成形機を用いて小型の小野式回転曲げ 疲労試験片を作製した。得られた成形体は，まず溶媒抽出に 
より主にワックス成分を除去したのち， $\mathrm{H}_{2} / \mathrm{N}_{2}$ 混合ガス雾囲気 中で残りのバインダを加熱揮散させた. 焼結は同じく $\mathrm{H}_{2} / \mathrm{N}_{2}$ 混 合ガス雾囲気を用いて最終炭素量を0.4mass\%となるように調 整し，焼結後の試料は密度測定および炭素分析等に供した。 また，熱処理として Arガス雾囲気中 1173Kで 1.8ks 溶体化処 理後, 油焼入れし, Ar ガス雾囲気中 $473 \mathrm{~K} て ゙ 3.6 \mathrm{ks}$ の焼もどし を施して, 引張試験，硬度試験，ならびに回転曲げ疲労試験 により各種機械的性質を調查した．なお疲労試験には，島津 製作所製小野式 $1.5 \mathrm{kgm}$ 回転曲げ疲労試験機 (回転数: 的 3000 rpm)を用いた.

\section{3 実験結果およひ考察}

\section{1 炭素量ならびに密度}

本鋼種における最終炭素量は $0.4 \mathrm{mass} \%$ を目標とするが， MIMプロセスにより焼結合金鋼を作製する場合, 脱バインダ および焼結工程においてバインダの分解によるFe粉末中への 炭素の拡散や，炉内の還元雾囲気および原料粉末中の含有酸 素による脱炭反応などにより，焼結後の炭素量は著しく変化 する。このため炭素量を厳密に制御することは困難とされて いるが，著者らは脱バインダおよび焼結時の雾囲気を調整す るだけで，かなり正確に炭素量を制御できることを見い出し ている゙2. 本実験では脱バインダ(加熱揮散)時に $20 \% \mathrm{H}_{2} / \mathrm{N}_{2}$ 組 成の湿合ガス，ならびに焼結時に $40 \sim 85 \% \mathrm{H}_{2} / \mathrm{N}_{2}$ 組成の混合ガ スを用いることで，焼結後の最終炭素量を $0.4 \pm 0.05$ mass\%に

Table 1 Characteristics of the powders used in this study.

\begin{tabular}{ccccc}
\hline & $\begin{array}{c}\mathrm{Fe} \\
(0.8 \% \mathrm{C} 0.3 \% 0)\end{array}$ & $\mathrm{Ni}$ & $\mathrm{Mo}$ & $\mathrm{Fe}-\mathrm{Mn}$ \\
\hline $\begin{array}{c}\text { Mean particle } \\
\text { size }(\mu \mathrm{m})\end{array}$ & 4.6 & 5 & 4 & 30 \\
\hline Particle shape & Spherical & $\begin{array}{c}\text { Spherical } \\
\text { with spike }\end{array}$ & Polygonal & Angular \\
\hline
\end{tabular}

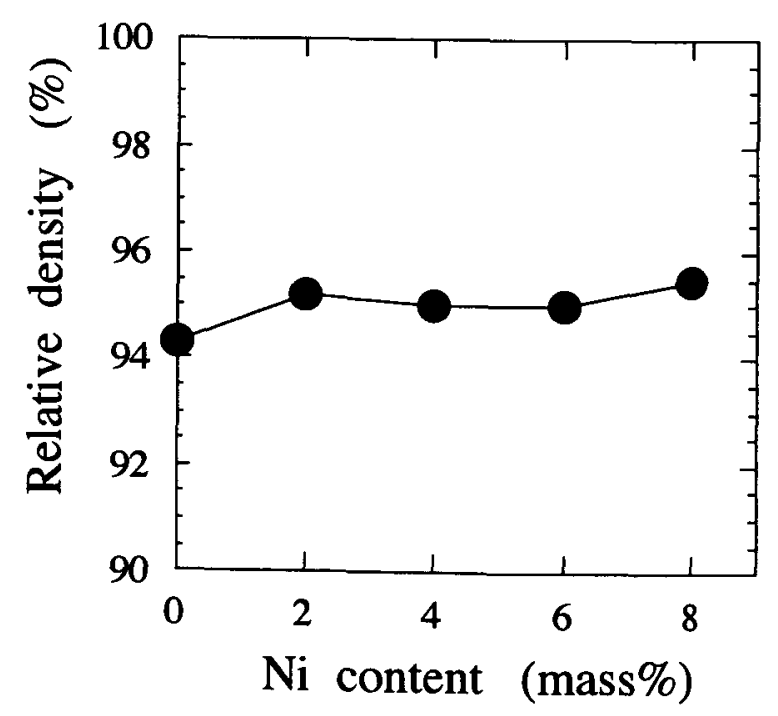

Fig.1 Effect of Ni content on the sintered density of MIM Fe-NiMo steels.
制御することができた。

得られた各種 Ni 添加材の焼結密度を Fig.1に示す.いずれ の組成においても $95 \%$ 前後の相対密度が得られており，気孔 は高密度材特有の微細な独立球状気孔であった. なお, Fe粉 末への微細 Ni 粉末の添加は焼結における編密化を促進させるす ことが知られているが, 本実験では顕著な効果は現れなかっ た.

\section{2 各種機械的性質}

本鋼種のような機械構造用鋼の場合，用途に応じて熱処理 を施すことが多い．そこで各種 Ni 添加材に $473 \mathrm{~K} て ゙$ 焼もどし を施し，各種機械的性質について調査した. Fig.2に引張強度 ならびに伸びの結果を示す．これより，伸びを損なうことな く引張強度はNi添加量の增加とともに飛唯的に上昇している ことがわかる.とくに 6 mass\% $\mathrm{Ni}$ 添加材においては, 引張強度 が約 2000MPa で伸びは約 5\%を示すなど，超強勒な特性を示 しており，注目に值する.しかしながら，8mass\%Ni添加材で は伸びの劣化は見られないものの, 引張強度がかなり低下し た.

次に回転曲げ疲労試験の結果をFig.3に示す. 引張強度と同 様に $\mathrm{Ni}$ 添加量の增加に伴い疲労強度は上昇し, $6 \mathrm{mass} \% \mathrm{Ni}$ 添 加材で最高值を示したが, 8mass\%Ni添加材においては疲労強 度は低下した。

\section{3 メゾへテロ組織の有効性}

各種機械的性質の挙動について組織学的観点より調查, 検 討した. 473K 焼もどし材の組織を Fig.4に示す．基地組織は 鈥もどしマルテンサイトであり，いずれの試料もところどこ ろに丸味を帯びた白色部が点在する微細な不均質組織を呈し ている.これまでの研究 ${ }^{2.3}$ により, 白色部は $\mathrm{Ni} の$ 偏析による

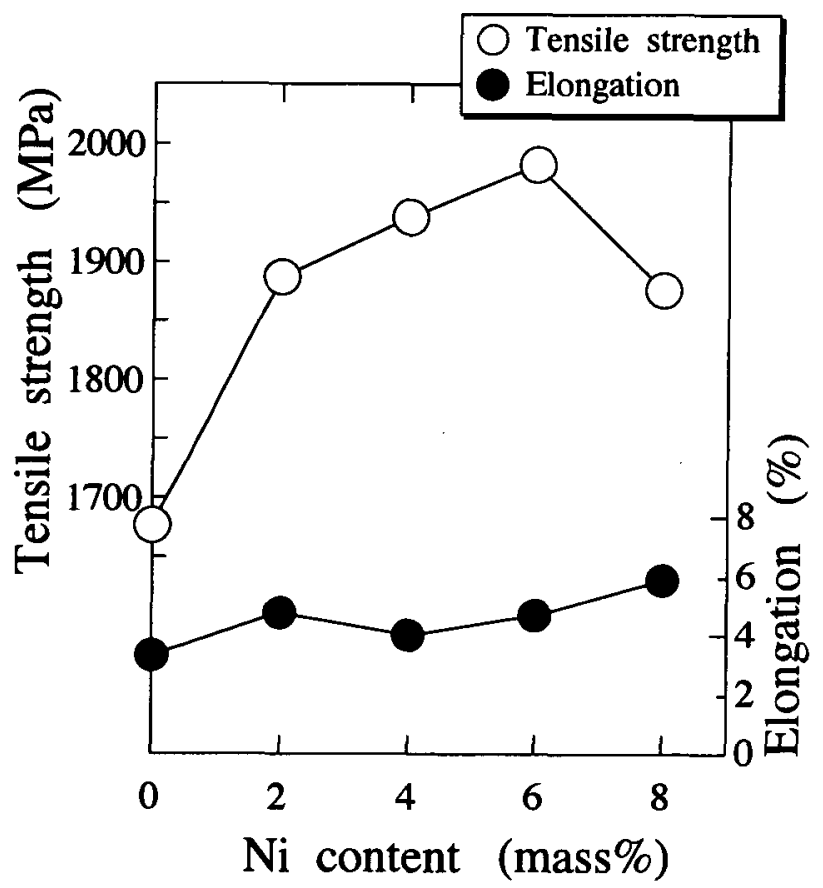

Fig.2 Effect of Ni content on the tensile properties of MIM Fe-NiMo steels tempered at $473 \mathrm{~K}$. 
高硬度なマルテンサイトであると推察され, 本試料において も EPMAにより Niに富んだ領域 (Niリッチ相)であることが 確認された. しかしながら, $\mathrm{Ni}$ を添加しない試料においても 若干ではあるが白色の組織 (矢印で示す) が観察され, EPMA による元素分析を行ったところ, Moならびに Mn が偏析して いた. とくに中央部に比較的大きな球状の気孔を有する白色 部には主に Mo が偏析しており, Fe, Moの相互間における拡 散速度の著しい差異 ${ }^{5}$ に起因したものと考えられる. いずれ にしても Fig.4より, Ni添加量の増加に伴い白色部の割合が増 加していることから，まずこれら組織の定量化を試みた。 そ の結果をFig.5に示すが, Niリッチ相の割合が増加しているこ

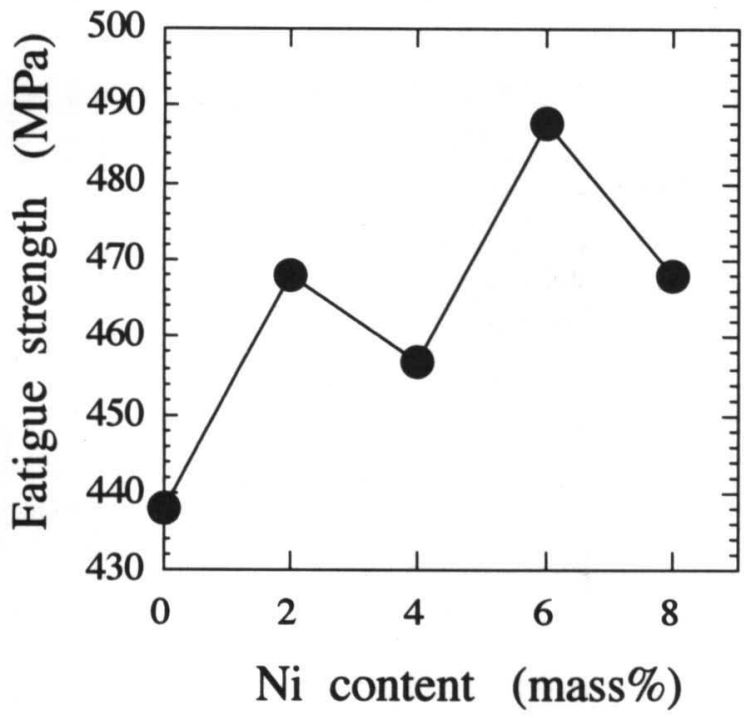

Fig.3 Effect of Ni content on the fatigue strength of MIM Fe-NiMo steels tempered at $473 \mathrm{~K}$
とがわかる. また基地 (白色部の周囲)のビッカース硬度を Fig.6に示すが, Ni添加量の増加に伴い確実に上昇しているこ とがわかる. つまり, Ni添加量が増すと高硬度なマルテンサ イト相の割合が増加するとともに，それらを網目状に焼もど しマルテンサイト相が取り囲んでおり,このことが各種機械 的性質の向上に寄与したといえる.

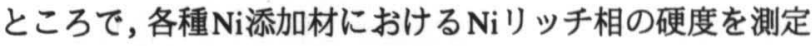
したところ, 約 $610 \mathrm{Hv}$ と基地よりも高い硬度を示すものもあ れば, $390 \mathrm{Hv}$ 程度の低い硬度を示すものも存在した. そこで,

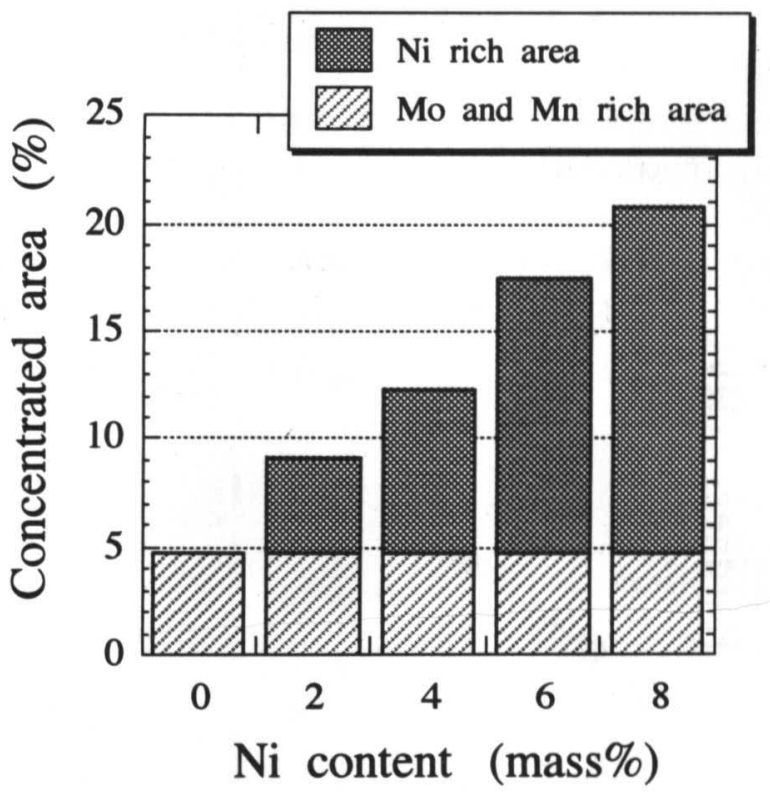

Fig.5 Fraction of the concentrated area of MIM Fe-Ni-Mo steels tempered at $473 \mathrm{~K}$.

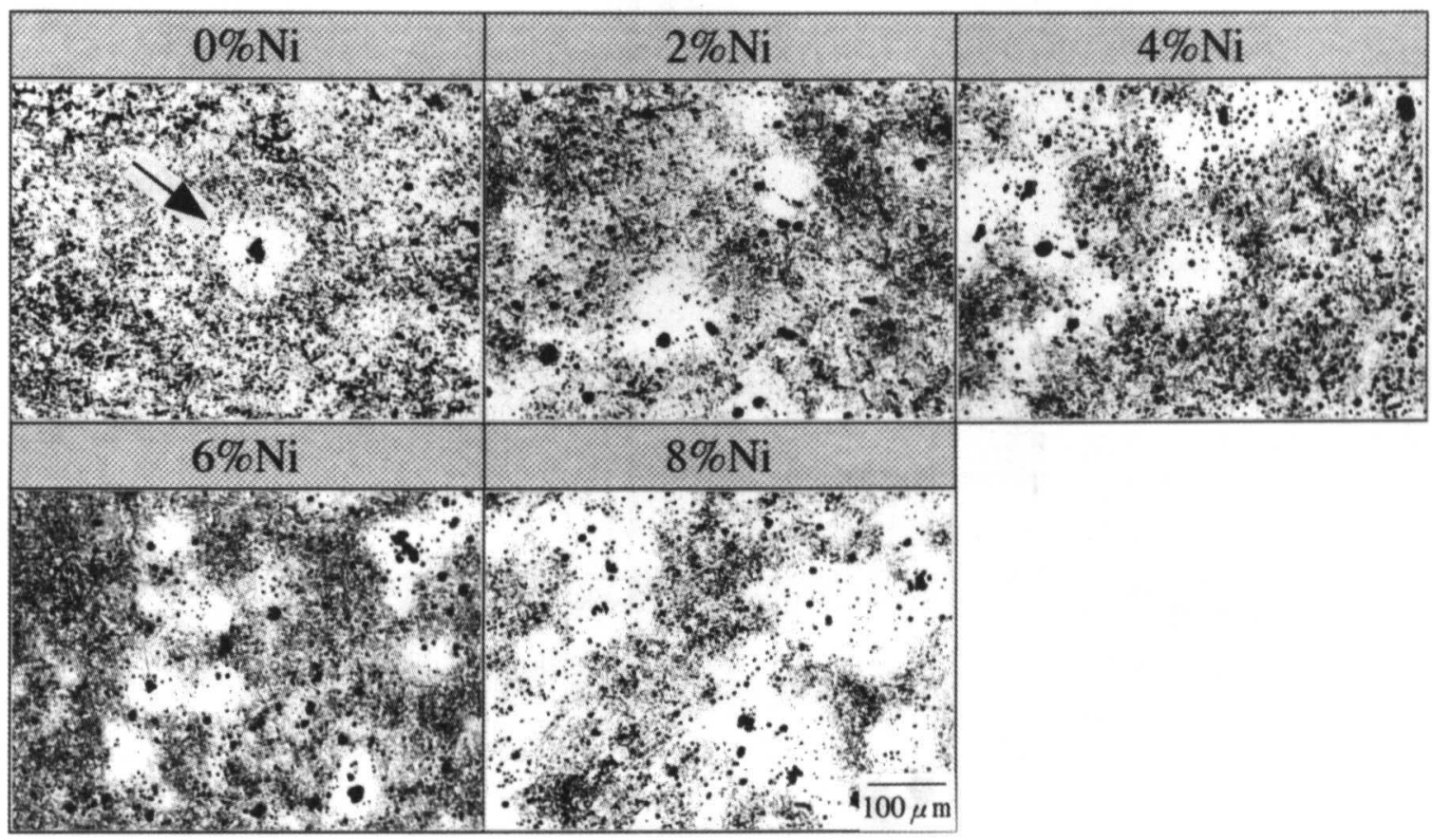

Fig.4 Microstructures of MIM Fe-Ni-Mo steels tempered at $473 \mathrm{~K}$. 
$\mathrm{X}$ 線回折による相の同定を行ったところ，微量ではあるが オーステナイトのピークが確認されたので, 以下の式より オーステナイトの定量化を試みた. 結果を Fig.7に示す.

$$
\gamma \text { 量 }(\%)=\left\{1 /\left(1+1 / \mathrm{K} \cdot \mathrm{I}_{\alpha} / \mathrm{I}_{y}\right)\right\} \times 100
$$

ここで $I_{\alpha}$ は $\alpha(211)$ の積分強度， $I_{\gamma}$ は $\gamma(220)$ と $\gamma(311)$ の積分 強度の平均值である.Kは物質によって決まる定数で，単位 格子の体積, 構造因子, 多重度因子ならびにローレンツ因子 等を測定して求めなければならないが, 一般に合金鋼におけ るKは1.4として用いても実用的には十分であるのことから， 本実験においてもこの值を使用した. Fig.7より, Ni添加量の 増加に伴いオーステナイト量も增加していることが確認でき る. また Fig.8に, 各種 Ni添加材における Ni リッチ相の中心 からのEPMA分析による Ni濃度のプロフィールを示す.いず

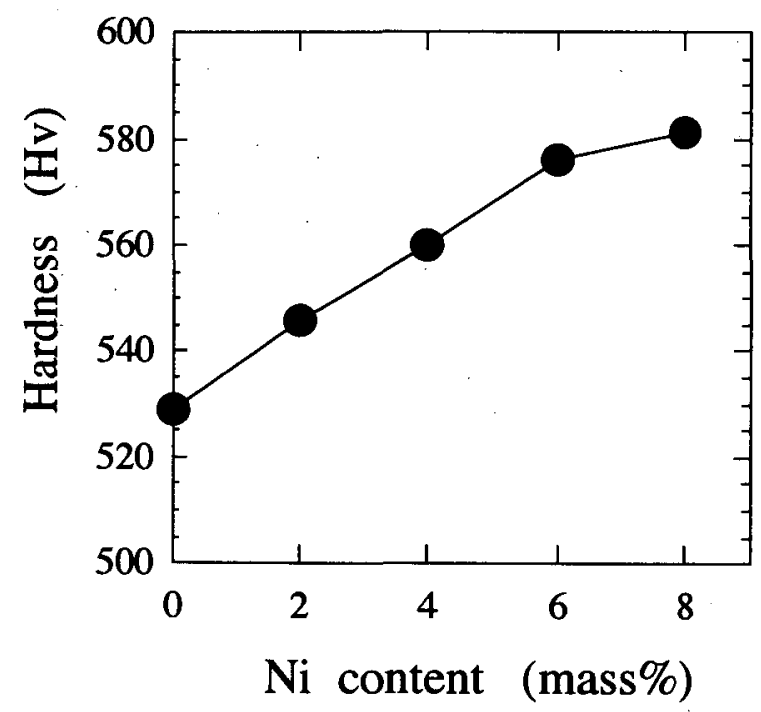

Fig.6 Effect of Ni content on the hardness of the matrix of MIM Fe-Ni-Mo steels tempered at $473 \mathrm{~K}$.

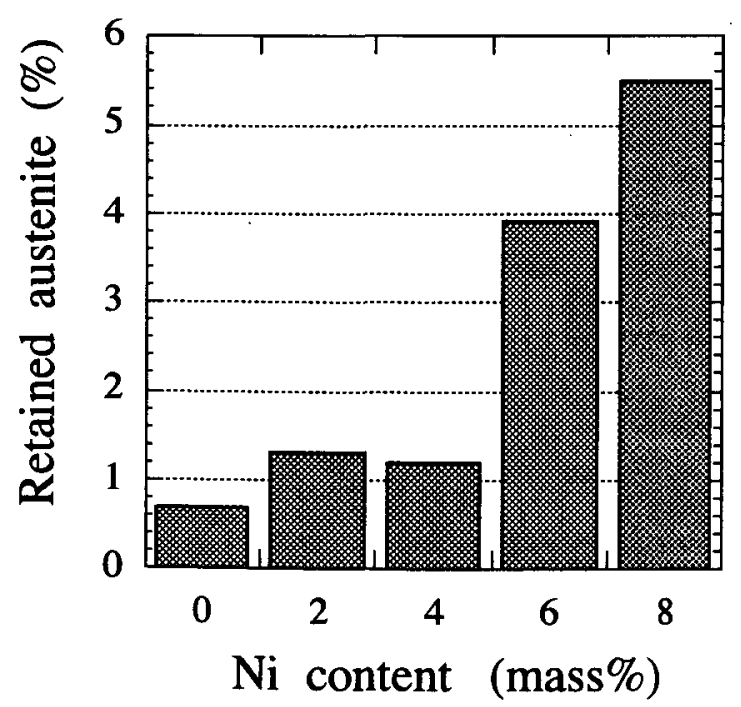

Fig.7 Fraction of the retained austenite of MIM Fe-Ni-Mo steels tempered at $473 \mathrm{~K}$.
れの試料においても添加量から約1２mass\%低い濃度のNiかs 基地には拡散しており， Ni リッチ相の大まかな領域としては $80 \mu \mathrm{m}$ 程度であった. また $\mathrm{Ni}$ 添加量の増加に伴い, Ni リッチ 相内の $\mathrm{Ni}$ 濃度も徐々に增加する傾向にあった. 以上のことか ら, 白色部の高 $\mathrm{Ni}$ 濃度のものでは Ms 点が低下して常温でも 軟らかい残留オーステナイトとなっており，それらが增加し た $8 \mathrm{mass} \% \mathrm{Ni}$ 添加材で弓張およひ疲労強度が低下したと推察 される。

最後に比較として，本鋼種の粉末鐉造材，MIM材ならびに プレス材の各種機械的性質を Table 2 に示す.なお；熱処理は 全ての試料において，Arガス雲囲気中 $1173 \mathrm{~K} て ゙ 1.8 \mathrm{ks}$ 溶体化 処理後, 油焼入れし，Arガス雾囲気中 473Kで 3.6ks の焼もど しを施した. MIM材の引張や疲労強度, 伸びともにプレス材 のそれらをはるかに凌き，粉末鍛造材に近ずく特性を示して いることがわかる.また均質材との比較を行う意味で，混合 粉末を用いて高温長時間焼結 $(1623 \mathrm{~K} \times 18 \mathrm{ks})$ により各種元素の 偏析のない均㙺な組織を呈する熱処理材の引張試験を行った ところ，メソへテロ組織を呈する試料とは $200 \mathrm{MPa}$ 程度低い

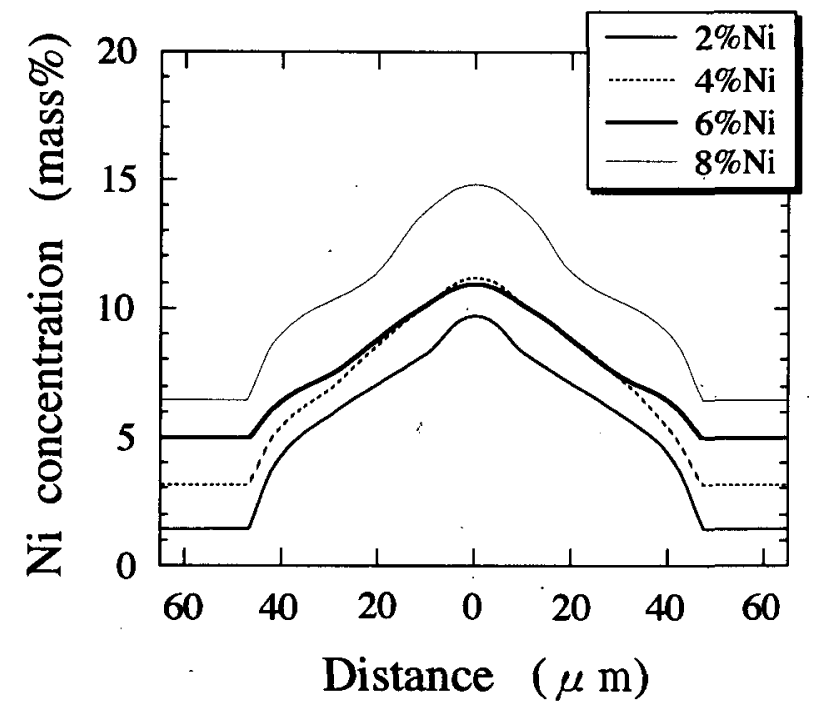

Fig.8 Profile of Ni concentration in the white region of MIM Fe$\mathrm{Ni}-\mathrm{Mo}$ steels tempered at $473 \mathrm{~K}$.

Table 2 Mechanical properties of the Fe-Ni-Mo steels produced by various processes.

\begin{tabular}{|c|c|c|c|c|}
\hline & PM (Forged) & $\begin{array}{l}\text { MiM } \\
\text { (6mass\% } \mathrm{Ni}) \\
\text { heterogeneity }\end{array}$ & $\begin{array}{l}\text { UiM } \\
\text { (6mass\% Ni) } \\
\text { homogeneity }\end{array}$ & $\mathrm{PAM}$ (Pressed) \\
\hline Density (\%) & 99.9 & $95^{*}$ & $96^{* *}$ & 92.4 \\
\hline $\begin{array}{c}\text { Tensile strength } \\
\text { (MPa) }\end{array}$ & 2115 & $\begin{array}{c}1983 \\
\max .2047\end{array}$ & $\begin{array}{c}1789 \\
\max .1808\end{array}$ & $\begin{array}{c}1443 \\
\max .1514 \\
\end{array}$ \\
\hline Elongation (\%) & .11 & 5 & 6 & 2 \\
\hline $\begin{array}{l}\text { Fatigue strength } \\
\text { (MPa) }\end{array}$ & 652 & 488 & - & 463 \\
\hline
\end{tabular}


強度を示したことからも，焼結低合金鋼の強勒化に対するメ ソヘテテロ組織の有效性が確認された。

\section{4 結 言}

代表的な機械構造用鋼種である4600鋼の組成を基に, $\mathrm{Ni}$ 添 加量を0〜8mass\%に変化させたMIM材を作製し，その熱処理 材の各種機械的性質におよほすメゾへテロ組織の影響を調查, 検討した結果, 以下の結論を得た.

（1）熱処理後の基地組織は嬅もどしマルテンサイトであり，い ずれの試料も Niリッチ相ならびに Fe, Moの相互間におけ る抬散速度の著しい差異に起因したMoリッチ相が点在し たメゾヘテロ組織を呈していた。

(2) $\mathrm{Ni}$ 添加量の增加に伴い, 延性を損なうことなく引張, 疲労 強度はともに飛躍的に上昇し，とくに 6 mass\% $\mathrm{Ni}$ 添加材に おいては引張強度が約 $2000 \mathrm{MPa}$ で伸びは約 5\% を示すな ど, 超強勒な特性を示した.これは, 基地自体が固溶強化 したことに加え，高硬度なマルテンサイト相の割合加増加 し,それらを網目状に焼もどしマルテンサイト相が取り囲 んでいることに起因したものといえる.

(3) 白色部において高 $N$ i 湭度のものでは, Ms点が低下して常
温でも軟らかい残留オーステナイトが出現し，それらが增 加する $8 \mathrm{mass} \% \mathrm{Ni}$ 添加材で引張および疲労強度は低下した.

\section{文献}

1）例えば R.M.German( 著)，三浦秀士，高木研一 (共訳): 粉末 冶金の科学, 内田老鶴圃, (1996).

2) 三浦秀士, 本田忠敏, R.M.German: "射出成形法による焼結 4600 鋼の機械的性質", 粉体および粉末治金, 39(1992)254259.

3）馬場剛治, 本田忠敏,三浦秀士: "MIMプロセスによる4600 鋼の疲労特性に及ぼす均質および不均質組織の影響", 粉体 および粉末治金, 44(1997)443-447.

4) 花立有功, 真島一彦, 三谷祐康: " $\mathrm{Ni}$ 添加による $\mathrm{Fe}$ 系圧粉 体の活性化焼結について", 日本金属学会誌, 40(1976)10101015.

5) 田辺重則, 森田明宏, 柴田治郎, 朝倉健二 : " 鉄一モリブデ ン合金の $\alpha, \gamma$ 相における焼結挙動", 粉体および粉末冶金, 35(1988)233-238.

6) 内藤武志："浸炭焼入れの実際", 日刊工業新聞社, (1979) 242 . 